\title{
イベントの時系列分析による因果関係知識の獲得
}

\section{Extracting Causal Knowledge by Time Series Analysis of Events}

\author{
小野 博紀 \\ 電気通信大学大学院情報理工学研究科総合情報学専攻 \\ Department of Informatics, The University of Electro-communications \\ ono1119@utm.inf.uec.ac.jp \\ 内海 彰 (同上) \\ Akira Utsumi utsumi@uec.ac.jp
}

keywords: causal knowledge, time series analysis, relation extraction

\begin{abstract}
Summary
Causal knowledge is important for decision-making and risk aversion. However, it takes much time and effort to extract causal knowledge manually from a large-scale corpus. Therefore, many studies have proposed several methods for automatically extracting causal knowledge. These methods use a variety of linguistic or textual cues indicating causality on the basis of the assumption that causally related events tend to co-occur within a document. However, because of this assumption, they cannot extract causal knowledge that is not explicitly described in a document. Therefore, in this paper, we propose a novel method for extracting causal knowledge not explicitly described in a document using time series analysis of events. In our method, event expressions, which are represented by a pair of a noun phrase and a verb phrase, are extracted from newspaper articles. These extracted event expressions are clustered into distinct events, and the burst of the appearance of these clustered events is detected. Finally, using the time series data with burst, it is judged whether any event pairs have a causal relationship by Granger Causality test. We demonstrate through an evaluation experiment that the proposed method successfully extracts valid causal knowledge, almost all of which cannot be extracted by existing cue-based methods.
\end{abstract}

\section{1. は じめに}

因果関係に関する知識は, 意思決定やリスク回避を行 うとき, 重要な知識源となる。しかし，大規模な文書集 合から人手で因果関係に関する知識を獲得するのはコス トと時間がかか，かつ多くの事象が絡み合っているた め容易ではない .

乥こで, 文書集合から自動的に因果関係知識を獲得す る研究が行われている . 例えば，「に伴う」や「を理由に」 といった手がかり表現を用いる手法 [Girju 03, 佐藤 06] や，構文パターンを用いる手法 [坂地 08, Khoo 00] , 動 詞並列句に注目した手法 [Torisawa 03] などが提案され ている .これらの研究の多くは因果関係にある事象対は 文書内で共起しやすいという特性 [乾 05] を利用してい るため, 文書内で共起しない事象対については考慮され ていない，关のため，「金利が下がれば景気が上がる」と いった，人は社会的常識として認識しているが明示的に 文書に書かれていない因果関係知識は獲得しづらい .

关こで本研究では, 文書に明示的に書かれていない因 果関係知識を抽出することを目的とする .この目的を達 成するために本研究で提案する抽出手法では, まず, 文 書から樣々なイベントに関する記述 (イベント表現) を抽 出し，光れらをイベントごとにクラスタリングする . 次 に，イベントごとのイベント表現を時系列に並べたデー
タに対してバースト検出を行う．バーストとは，ある種 のデータが突然, 急激に増加する現象のことである.よっ て，イベントの時系列データに対してバースト検出を行 うことで，イベントが集中的に話題となった時期を特定 することができる．イベントが話題となった時期はイべ ントの発生時期の妥当な近似とみなすことができるので， バースト検出によってイベントの発生時期を同定するこ とが期待できる. 光して最後に, 提案手法では, バース 卜の時系列データ間に統計的に因果性があると判断され たイベント対を因果関係知識として抽出する . 統計的な 因果性の判断には, 経済学の分野で一般的に用いられる グレンジャー因果性検定を利用する．

文書中に明示的に書かれていない因果関係知識の抽出 を試みることで, 我々が常識として認識している知識だ けではなく，新たな知識発見となる因果関係知識の抽出 が期待できる.光して, 本手法で得られた因果関係知識 は，経济や政治などの社会科学分野における事象の予測 モデル [菅野 94]や，兴のような予測を行う人間の思考 モデルの構築などへの応用を考えることができる．

本論文の以下では, 2 章で関連研究について言及し, 本 研究の位置づけを述べる. 3 章では提案手法のアルゴリ ズムを示す．光して，4 章では提案手法を評価するため の実験と谷の結果，考察について述べる． 


\section{2. 関 連 研 究}

Girij ら [Girju 03] や佐藤ら [佐藤 06] は,「に伴う」や 「cause」というような因果関係を表す手がかり表現を用 いて，因果関係知識を獲得する手法を提案している。さ らに坂地ら [坂地 08]や，Khoo ら [Khoo 00] は因果関 係を表す構文パターンを用いた知識獲得手法を提案して いる。

また, 上記で挙げた研究とは違い, 手がかり表現や 構文パターンに依存しない手法も提案されている. Trisawa[Torisawa 03] は並列句が一つの文に存在し, 並列句 中の動詞が共通の目的語を持つ場合, 因果関係が成立し やすいと仮定して，統計的に因果関係を抽出する手法を 提案している. Chang[Chang 04] や山田ら [山田 05] は 因果関係にある単語ぺアと構文構造を学習する手法を提 案している.この手法は, 並列句中の動詞が共通の目的 語を持たない場合にも対処可能である．

さらに, 単語単位ではなく, 動詞や目的語を含んだイベ ント単位での因果関係抽出も行われている.Riazら [Riaz 10] は文で構成されたクラスタによってイベントを表現し て, 弚れらのイベント間の因果関係を求める研究を行っ ている . Doら [Do 11] は動詞が表現するイベントと，人 手で作成したルールを用いて生成した名詞化表現を抽出


かを相互情報量などを用いることで判定，抽出している．

因果関係の抽出とともに, 分類を行った研究もある. 乾 ら [乾 04] は手がかり表現「ため」を用いて知識を抽出し， 光れらを 4 つの因果関係 (cause, effect, precond,means) に分類する手法を提案している.

これまでに挙げたすべての関連研究は，因果関係にあ る事象対は文書内で共起しやすいという因果関係の出現 特性 [乾 05] 利用しているが，本研究では光の特性を 利用しない．この特性を利用しないことによって，既知 の因果関係知識だけでなく, 新たな知識発見となる因果 関係知の獲得が期待できる.

因果関係の出現特性を利用せず，因果関係を抽出する 試みも行われている.Sun ら [Sun 07] は検索エンジンの クェリのログから因果関係を抽出する手法を提案してい る.この研究では, 検索回数が急激に上昇した日時に何 らかのイベントが発生したとみなし，兴のイベント間の 発生した時間に着目して因果関係の抽出を試みている この研究の解析対象は検索エンジンのログであり，さら に因果関係知識における事象はクェリであるが, 本研究 では新聞記事が解析対象であり，事象はイベントである

\section{3. 提 案 手 法}

\section{$3 \cdot 1$ 概 要}

本手法では，まず，新聞記事から「 $\mathrm{NP}$ が VPした」と いう単位でイベントについての記述 (以降, イベント表現

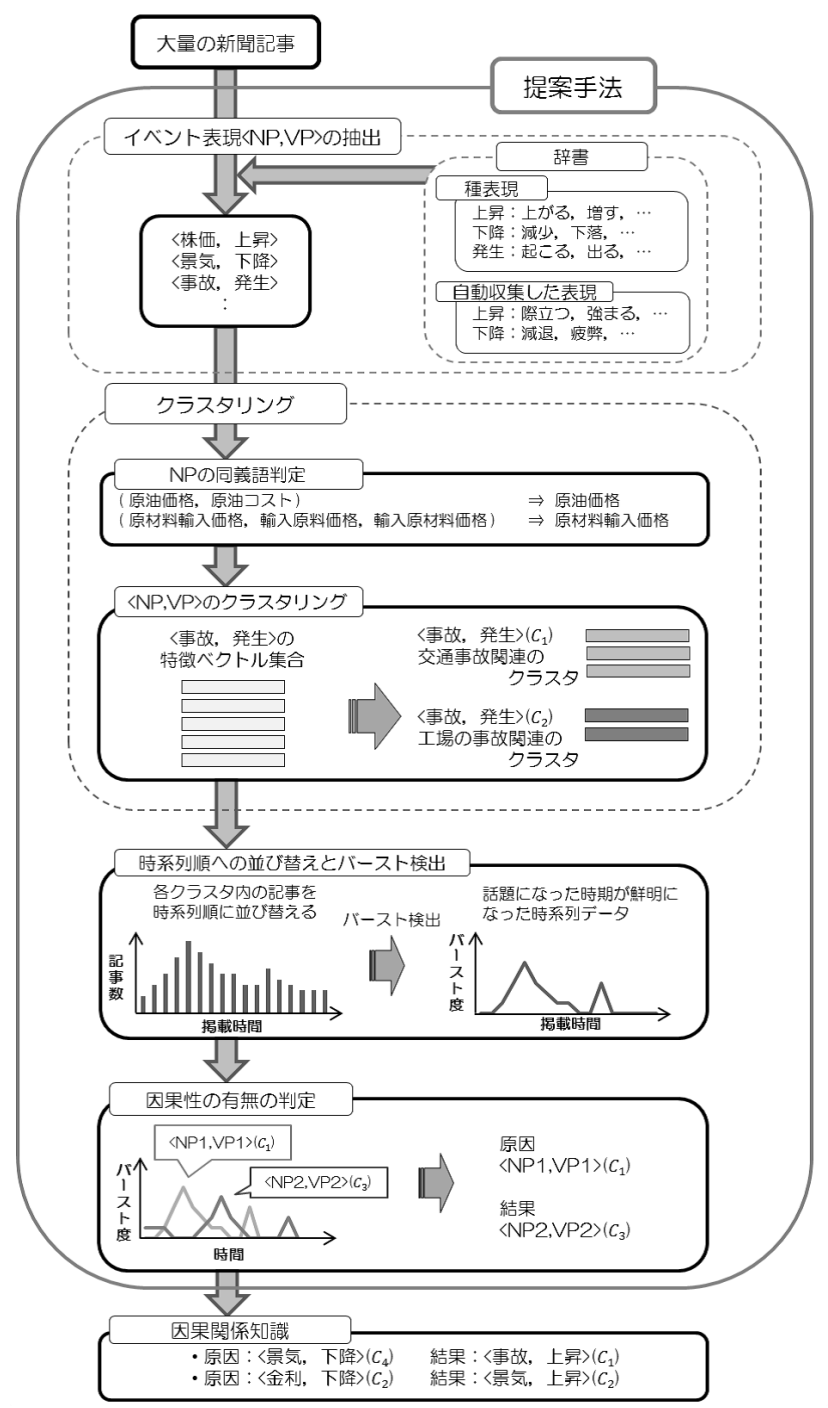

図 1 提案する因果関係知識の抽出手法の流れ

$\langle N P, V P\rangle$ と記す) を収集する.次に，同一の $\langle N P, V P\rangle$ であるイベント表現集合に対して, 話題ごとに分類する ためのクラスタリングを行い, 得られた各クラスタを 1 つのイベントとみなす．乥して，各イベントに含まれる全 てのイベント表現を 1 週間を単位として新聞記事への掲 載時間に基づいて時系列順に並び替え，兴の時系列デー タに対してバースト検出を行い，㚇のイベントが集中し て話題となった時期を特定した時系列データへ変換する． 最後に，弚れらの時系列データを対象に，グレンジャー 因果性検定を用いて統計的に因果関係があると判断され たイベント対を因果関係知識として抽出する

このように, 本手法は多くの既存研究で用いられてき た，因果関係である $2 つ の$ 事象は文書内で共起しやすい という前提を用いずに，イベントが発生した時期に対し て統計的分析を行うことで，因果関係知識を抽出する.本 手法の全体図を図 1 に示す.

本手法は, 大きく分けて以下の 4 つの段階で構成され ている. 
（1）イベント表現 $\langle N P, V P\rangle$ の収集

（2）イベント表現のクラスタリングによるイベントの 同定

(3) 各イベントの時系列データに対するバースト検出

（4）イベント間の因果性の有無の判定

以下，弚れ光れの手順の詳細を述べる。

\section{$3 \cdot 2$ イベント表現 $\langle N P, V P\rangle$ の収集}

以下の手順に従って，イベント表現 $\langle N P, V P\rangle$ をテキ ストから抽出する

手順 1 格助詞「が，は」を含む文節が動詞，及びサ変

接続の名詞に係っている場合，この名詞句 $N P$ と動 詞句 $V P$ のペアを 1 つのイベント表現 $\langle N P, V P\rangle$ と して収集する。

手順 2 辞書を用いて, $V P$ が「上昇，下降，発生」の

いずれかに分類されるイベント表現のみを解析対象 として抽出する .

手順 1 において, 単純に上記の方法でイベント表現の 抽出を行うと「景気が上がれば，〜なる」といった仮定の 意味で用いられるイベント表現も抽出されてしまうため， $V P$ に助動詞「た」の仮定形, もしくは接続助詞「ば」が 含まれる場合，抽出対象から除く．また，抽出した $N P$ が「こと」であった場合，こと」と关の文節に係る文節 を結合して 1 つの $N P$ とする .これは,「見ること」のよ うな表現の場合，2つの文節に別れてしまうからである.

手順 2 では,「上昇，下降，発生」のいずれかに分類さ れる動詞句のみを対象とする . 例えば，〈一年,過ぎる〉 というイベントがあった場合，VP (過ぎる) は「上昇， 下降，発生」のいずれにも分類されないため抽出対象と ならないが，〈景気,上がる〉は $V P$ (上がる) が上昇に 分類されるため抽出対象となる. 弚して, 本手法のこれ 以降の処理においては, イベント表現の $V P$ は「上昇」, 「下降」，「発生」のいずれかとして扱う。つまり，例え ば「増加」,「増す」,「高まる」といった動詞句はすべて $\ulcorner V P=$ 上昇」として扱う．

動詞句 $V P$ を「上昇，下降，発生」に分類するために， 本研究では以下の方法で辞書を作成する.

\section{$\S 1$ 辞書の作成方法}

判定に用いる辞書は, まず人手で簡単な辞書を作成す る.この辞書の語句数が多ければ多いほど, 多くのイベ ント表現を抽出できることになる．乥こで，上昇，下降 の辞書については自動的に拡張を行い, 最後に, 拡張し た辞書から人手で適切でない表現を除いた辞書を，VP の分類に用いる．なお，発生を表す語句は上昇・下降を 表す語句に比べて少なく，人手で用意した語句のみで対 応できると考えたため, 発生の辞書の自動的な拡張は行 わない.

自動的な辞書の拡張は, 人手で作成した辞書に含まれ る語句を種表現として，以下の 3 つの手順により行う .
手順 1 上昇・下降するものごとを表す $N P$ を種表現を 用いて収集する。

手順 2 手順 1 で収集された $N P$ が係る $V P$ を収集し， 自己相互情報量 PMI を用いてフィルタリングを行う . 手順 3 手順 2 で得られた $V P$ を種表現と時間情報を用

いて上昇・下降・光の他のいずれかに分類する． 以下，弚れ光れの手順の詳細について述べる。

i. 手順 1

ここでは, 上昇・下降するものごと（上昇や下降とい う状態を持つものごと) を表す $N P$ を収集することを目 的としている，乥こで，人手で作成した辞書に含まれる 語句を種表現として, 上昇・下降の種表現に係るすべて の $N P$ を変化の可能性を持つ $N P$ として収集する .

ii. 手順 2

手順 1 で収集された $N P$ が係る動詞（またはサ変接続 の名詞) から始まる文節 $V P$ を収集する.乥して，この 文節から助動詞「ない」以外の助動詞, 助詞, 記号, 数 字を除去し，残った動詞についても原形に変換する。例 えば,「供給されて,という文節は,「供給するれる」と 変換される .これは, 上記の例や「激化したが 」という ように，文節末に助詞や記号などが含まれていても，同 じ語句として扱えるようにするための処理である .

乥して、「ない」や「する」といった明らかに変化を表 さない $V P$ を，自己相互情報量 PMI を用いて除外する $N P$ と VPのPMI の值が閾値 $\beta$ より小さい場合，光の $V P$ を変化を表さない一般的な語句と見なして候補から 取り除く.PMI は (1) 式で計算され, 辞書に加える条件 は (2) 式となる .

$$
\begin{aligned}
& P M I\left(p h_{i}, p h_{j}\right)=\log \frac{p\left(p h_{i}, p h_{j}\right)}{p\left(p h_{i}\right) p\left(p h_{j}\right)} \\
& P M I\left(p h_{i}, p h_{j}\right) \geq \beta
\end{aligned}
$$

ただし, $p\left(p h_{i}\right)$ は句 $p h_{i}$ の出現確率, $p\left(p h_{i}, p h_{j}\right)$ は句 $p h_{i}$ と $p h_{j}$ の同時出現確率を表す.

\section{iii. 手順 3}

手順 2 で収集された光れ光れの $V P$ を，上昇・下降・光

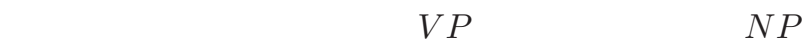
に対して, 兴の表現を含む記事の前後 3 日以内の記事中 でその $N P$ か種表現に係っている場合，弚の $V P$ を兴の 種表現と同じカテゴリ (上昇か下降) に分類する.ひと つの $V P$ に対して複数の $N P$ による判断が一致しない 場合には，多数決によって分類カテゴリを決定する．な お, 上昇・下降の判断が同数である場合は, 光の他に分 類する. 光して, 上記の方法で上昇・下降のどちらにも 分類されなかった $V P$ は, 弚の他に分類する.語 $\mathrm{A}$ か語 $\mathrm{B}$ に係ることを $「 \mathrm{~A} \rightarrow \mathrm{B}\lrcorner$ と表記すると，例えば，「競争 ＼cjkstart激化」というイベントの発生時期と同時期に「競争 $\rightarrow$ 増す」というイベントが述べられている場合，激化」は 「上昇」の意味を持つと分類される . 
$3 \cdot 3$ イベント表現のクラスタリングによるイベントの 同定

$3 \cdot 2$ 節で収集されたイベント表現を $N P$ かつ $V P$ が同

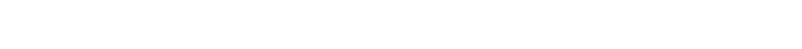
れのイベント表現集合に対してイベントを同定するため のクラスタリングを行う .これは, 図 1 で挙げた例〈事 故,発生〉のように, 同じイベント表現〈事故,発生〉で あっても交通事故関連のイベントであったり，工場の事 故関連のイベントであったりと，同じイベント表現が異 なるイベントを表すことが頻繁に生じるからである．こ のクラスタリングによって得られる弚れ光れのクラスタ が，因果関係知識を構成する 1 つのイベントとなる .

一方で，抽出されたイベントの $N P$ には，「資金ニー ズ」と「資金需要」「原油相場」と「原油価格」という ように同じ意味であっても異なる表記のものがある．乥 こで, 同じ意味である $N P$ につては, 表記が違ってい ても同じ $N P$ として扱えるように, クラスタリングの前 処理として $N P$ の同義性判定を行う .この同義性判定の 結果, ある複数の $N P$ がすべて同義であると判定された 場合，これらの $N P$ はすべて同一の $N P$ として扱った 上でクラスタリングを行う .

\section{$\S 1$ NP の同義性判定}

$N P$ の同義性判定は，2つの表現が同義語で構成され ているかどうかに着目して行う . 具体的には，ある2つ の名詞句 $N P_{1}$ と $N P_{2}$ に対して，以下の手順を適用する . 手順 $1 N P_{1}$ と $N P_{2}$ の兰れ光れに対して，形態素解析 での最小単位の単語に分割する. 得られた単語の集 合を $W_{1}, W_{2}$ とする。例えば， $N P_{1}$ が「原材料輸入 価格」のときには, $W_{1}=\{$ 原材料, 輸入, 価格 $\}$ と なる。

手順 $2 W_{1}$ と $W_{2}$ から, 記号,「など」, 接尾辞 ( 量 , 〜率など）を削除する．

手順 $3 W_{1}$ と $W_{2}$ の両方に存在する単語と，2つの集合 間で日本語 WordNet*1 を用いて同義語と判定される 単語のペアを $W_{1}, W_{2}$ から削除する.

手順 $4 W_{1}$ と $W_{2}$ がともに空集合となった場合， $W_{1}$ と $W_{2}$ は意味的に同じ単語のみで構成されているとい えるため，2 つの名詞句 $N P_{1}, N P_{2}$ が同義であると 判定する.

同義と判断された $N P$ は, 同義と判断された $N P$ 内の いずれかの $N P$ と置き換えて扱う．例えば，語 $t_{1}, t_{2}, t_{3}$ があり，同義性判定により $t_{1}=t_{2}, t_{2}=t_{3}$ と判断され た場合, 語 $t_{1}, t_{2}, t_{3}$ はすべて $t_{1}$ とみなして, 以後の処理 を行う.

$\S 2$ イベント表現 $\langle N P, V P\rangle$ のクラスタリング

本節では, 同じ話題内容のイベントごとに分けるため のクラスタリングを行う . 具体的には, $3 \cdot 2$ 節で抽出さ れたすべてのイベント表現に対して, 光の表現が出現し た新聞記事の情報を用いて特徵ベクトルを生成する，乥

*1 http://nlpwww.nict.go.jp/wn-ja/
して, $3 \cdot 3 \cdot 1$ 節の処理を通じて得られる $N P$ と $V P$ が同 一であるイベント表現の集合に対して，イベントを同定 するためのクラスタリングを行う .

あるイベント表現 $e_{i}$ の特徵ベクトル $e_{\boldsymbol{i}}$ (イベント表 現ベクトル) は，イベント表現が含まれる新聞記事に出 現する名詞 $t_{j}$ を要素として表現する.名詞が連続して出 現する複合名詞は，弚れらを 1 つ名詞として扱う。ベ クトルの各要素は (3) 式によって決定され，イベント表 現ベクトルは (4) 式で表現される .

$$
\begin{aligned}
w_{i}\left(t_{j}\right)=t f\left(d_{i}, t_{j}\right) & \times \log _{2} \frac{|D|}{d f\left(t_{j}\right)} \\
\times \frac{1}{1+\log \left(\operatorname{dist}\left(e_{i}, t_{j}\right)\right)} & \\
\boldsymbol{e}_{\boldsymbol{i}} & =\left(w_{i}\left(t_{1}\right), w_{i}\left(t_{2}\right), \ldots, w_{i}\left(t_{n}\right)\right)
\end{aligned}
$$

ただし, $t f\left(d_{i}, t_{j}\right)$ はイベント表現 $e_{i}$ を含む文書 $d_{i}$ 内で の語 $t_{j}$ の出現頻度， $|D|$ は総文書数,$d f\left(t_{j}\right)$ は語 $t_{j}$ の出 現する文書数, $\operatorname{dist}\left(e_{i}, t_{j}\right)$ は文書 $d_{i}$ においてイベント表 現 $e_{i}$ を含む文と語 $t_{j}$ を含む文の距離 (2 文間に存在す る文数+1) の最小值を表す . この重み付けは tf-idf 法を ベースとして，イベント表現に近い単語は光のイベント 表現が属する話題に関する語が記述されやすいという特 性を考慮している。

次に，これらのイベント表現ベクトルを行とするイベ ント表現・単語行列を作成し，この行列に対してLSA (潜 在的意味解析）により次元圧縮を行う.この結果得られた 特徵ベクトルを, 最終的なイベント表現ベクトルとする .

乥して，同一の $N P, V P$ を持つイベント表現の集合 $E=\left\{e_{1}, e_{2}, \ldots, e_{m}\right\}$ に対して，凝集型階層的クラスタ リング手法である Ward 法を用いてクラスタリングを行 う. イベント表現間の類似度は, イベント表現ベクトル 間のコサインにより計算する . 併合したクラスタ間の距 離と，次に併合するクラスタ間の距離の差が 0.5 を超え たときに，クラスタリングを終了する.結果として得ら れた各クラスタが個々のイベントを表すことになる .

\section{4 各イベントの時系列データに対するバースト検出}

$3 \cdot 3$ 節で生成された各イベントクラスタごとに，光の クラスタに含まれるイベント表現を，1週間を単位とし て新聞記事への掲載時間に基づいて時系列順に並び替え る. 乥して，このイベントの時系列データに対してバー スト検出を行う.

本手法でバースト検出を行う目的は以下のとおりであ る、バーストとは，ある時点からある話題に関する記述 が急激に増加する現象を指す，一般的に，イベントが集中 的に話題となったバースト時期は，実際にイベントが生 起した時期とおおよ光同じである.よって，バースト検出 を行うことによって，イベントの生起時期を反映した時 系列データを得ることが可能になり，光のようなデータ に対して 3.5 節で述べる統計的解析を行うことによって， 
実際に因果関係が存在するイベント対のみを検出する可 能性が高まることが期待できる．言い換えると，バース 卜期間以外 (話題となっていない時期) のイベント表現 は, 兴のイベントの生起と関係ないノイズとなるデータ であり，このようなデータを除去することによって，因果 関係が成立するイベント対を獲得しやすくなると言える . $\S 1$ バーストモデル

本研究では, Kleinberg[Kleinberg 03] のバースト検出 アルゴリズムの1つである Enumerating バーストを用い る . Enumerating バーストのアルゴリズムは, 離散時間 で送られる集合に対して適用される。

あるイベント (クラスタ) $E$ に対して，解析期間にお いて $n$ 個の記事集合列 $A_{1}, A_{2}, \ldots, A_{n}$ か漓倠散時間で送ら れてくる状況を考える. $t$ 番目の記事集合 $A_{t}$ に含まれる 記事の数を $d_{t}, A_{t}$ 中でイベント $E$ のイベント表現を含 む記事の数を $e_{t}$ とおく. 解析期間におけるすべての記事 の数 $D$ は $D=\sum_{t=1}^{n} d_{t}$, イベント $E$ のイベント表現を 含む記事の総数 $E_{\text {all }}$ は $E_{\text {all }}=\sum_{t=1}^{n} e_{t}$ と表すことがで きる .

次に, バースト状態と非バースト状態の 2 つの状態に 弚れ光れ確率を割り当てる. 非バース卜状態 $q_{0}$ には, 解 析期間全体を見たときの確率 $p_{0}=E_{\text {all }} / D$ を割り当てる. バースト状態 $q_{1}$ には, $p_{0}$ にパラメータ $s$ をかけた值であ る $p_{1}=s p_{0}$ を割り当てる.ただし， $s>1$ であり， $p_{1} \leq 1$ となるような $s$ でなくてはならない . 記事集合中にイべ ント表現を含む記事が二項分布 $B\left(d_{t}, p_{i}\right)$ にしたがって 現れるという考えに基づき，状態 $q_{i}$ にいることに対する コストを与える関数 $\sigma\left(i, e_{t}, d_{t}\right)$ は (5) 式のように定義さ れる .

$$
\sigma\left(i, e_{t}, d_{t}\right)=-\ln \left[\left(\begin{array}{l}
d_{t} \\
e_{t}
\end{array}\right) p_{i}^{e_{t}}\left(1-p_{i}\right)^{d_{t}-e_{t}}\right]
$$

光して, 期間 $t_{k}, \ldots, t_{l}$ におけるイベント $E$ のバースト度 $b\left(t_{k}, t_{l}, E\right)$ は (6) 式の式で定義される .

$$
b\left(t_{k}, t_{l}, E\right)=\sum_{t=t_{k}}^{t_{l}}\left(\sigma\left(0, e_{t}, d_{t}\right)-\sigma\left(1, e_{t}, d_{t}\right)\right)
$$

本手法では 1 週間ごとにバースト度を算出するため, $t_{k}=$ $t_{l}$ となる $\cdot$ よって , 期間 $t$ におけるあるイベント $E$ のバー スト度は (7) 式で計算される .

$$
b(t, E)=\sigma\left(0, e_{t}, d_{t}\right)-\sigma\left(1, e_{t}, d_{t}\right)
$$

ただし,$b(t, E)<0$ となった場合， $b(t, E)=0$ とする.

\section{$3 \cdot 5$ イベント 間の因果性の有無の判定}

$3 \cdot 3$ 節で得られたすべてのイベントに対して原因・結果 の方向性を考慮した総当りでイベント対を作成し, $3 \cdot 4$ 節 で計算された各イベント $E$ のバースト度 $b(t, E)$ の時系 列データを用いて，各イベント対の間に因果関係が成立 するかどうかを判定する . 因果性の判定にはグレンジャー
因果性検定 (Granger causality test) を用い，この検定で 有意となったイベント対を因果関係知識として抽出する. グレンジャー因果性検定は, 経済学における時系列分 析に基づく将来の予測によく用いられる，以下の統計的 手法である [沖本 10] .

フグレンジャー因果性検定

ある時系列データ $y_{1, t}, y_{2, t}$ があるとする . 現在と過 去の $y_{1, t}$ の值だけに基づいた将来の $y_{1, t}$ の予測と， 現在と過去の $y_{1, t}$ と $y_{2, t}$ の値に基づいた将来の $y_{1, t}$ の予測を比較して, 後者の平均二乗誤差 (MSE) の 方が統計的に有意に小さくなる場合， $y_{2, t}$ から $y_{1, t}$ への因果性 (「グレンジャー因果性」) が存在すると 判定する.

グレンジャー因果性検定は，イベント (事象) に関する 理論や知識を用いずに，因果関係の有無をデータだけか ら判断をしたいときに用いられる.本研究では, 2 つのイ ベント $E_{1}, E_{2}$ に対して $, y_{1, t}=b\left(t, E_{1}\right), y_{2, t}=b\left(t, E_{2}\right)$ としてグレンジャ一因果性検定を適用する .このとき，グ レンジャー因果性検定で有意となるのは，現在の $E_{1}$ の 話題の盛り上がりが, 過去の $E_{2}$ の盛り上がりと統計的 に関係があるときである .この検定を行うために推定す るべクトル自己回帰 (VAR) モデルは (8) 式で表される . 次数 $p$ については, AIC により選択する.

$$
\left\{\begin{aligned}
b\left(t, E_{1}\right)=c_{1} & +\phi_{11}^{(1)} b\left(t-1, E_{1}\right)+\phi_{12}^{(1)} b\left(t-1, E_{2}\right)+\cdots \\
& +\phi_{11}^{(p)} b\left(t-p, E_{1}\right)+\phi_{12}^{(p)} b\left(t-p, E_{2}\right)+\epsilon_{1 t} \\
b\left(t, E_{2}\right)=c_{2} & +\phi_{21}^{(1)} b\left(t-1, E_{1}\right)+\phi_{22}^{(1)} b\left(t-1, E_{2}\right)+\cdots \\
& +\phi_{21}^{(p)} b\left(t-p, E_{1}\right)+\phi_{22}^{(p)} b\left(t-p, E_{2}\right)+\epsilon_{2 t}
\end{aligned}\right.
$$

ただし, $c$ は定数， $\phi$ は係数， $\epsilon$ は誤差項を表す.

\section{4. 実験および評価}

\section{$4 \cdot 1$ 実 験 材 料}

実験に用いた新聞記事は，1996〜1997 年に発行され た毎日新聞，日経新聞，読売新聞の記事 890,041 件であ る.この記事集合に対して本手法を適用し，3·2·1 節で 述べた辞書の拡張と，因果関係知識の抽出を行った .な お, 係り受け解析器には CaboCha ${ }^{* 2}$, VAR モデルの推定 とグレンジャー因果性検定には R 言語のパッケージであ る $\operatorname{vars}^{* 3}$ を用いた。

$V P$ の分類に用いる辞書については, 表 1 に示す語句 を用意した. として, 表 1 に示した上昇, 下降の表現を 種表現として辞書の拡張を行った . なお, 閾値 $\beta=5$ と した .

LSA によるイベント表現ベクトルの次元圧縮の際 , 次 元数は 300 とした. 乥して, VAR モデルの推定では最

*2 http://code.google.com/p/cabocha/

*3 http://cran.r-project.org/web/packages/vars/ 
表 1 用意した辞書

\begin{tabular}{|c|c|}
\hline 属性 & 語句 \\
\hline 上昇 & $\begin{array}{l}\text { 増加, 増進 , 増す, 上昇, 高まる, } \\
\text { アップ, 上る, 膨れ上がる, 回復 , 再起 } \\
\text { 前進 , 上がる , 復活 , 復調 }\end{array}$ \\
\hline 下降 & $\begin{array}{l}\text { 下降, 減少, 縮小, 下落, 落ちる, 落ち込む, } \\
\text { ダウン, 低減, 低落, 悪化, 深刻化, 低下 }\end{array}$ \\
\hline 発生 & 起こる, 出る, 生じる, 生起, 発生, 発する \\
\hline
\end{tabular}

表 2 自動的に収集された語句の一部

\begin{tabular}{|c|c|}
\hline 属性 & 表現 \\
\hline 上昇 & $\begin{array}{l}\text { 上向きにある , 活発化, 重要になる } \\
\text { クローズアップされる, 熱中する }, \\
\text { はずむ , 膨張する , 食い違う }\end{array}$ \\
\hline 下降 & $\begin{array}{l}\text { 発揮できない, 急落する, 空回りする }, \\
\text { 下方修正する, ひどい, 急反落する }, \\
\text { 重要でなくなる, 赤字 , 汇濫する }\end{array}$ \\
\hline
\end{tabular}

大の次数を 8 とした . 本手法では 1 週間を単位としてい るため，これは最大 2 ヶのラグを考慮した推定となる。 また，バースト検出におけるパラメータ $s$ は既存研究を 参考に $s=2$ とし, グレンジャ一因果性検定は有意水準 $5 \%$ で行った . 検定の対象としたイベントは，3.3 節で述 ベた方法でクラスタリングを行った結果, クラスタの要 素数 (イベント表現の総数) が 100 を超えたものにした .

\section{$4 \cdot 2$ 結果}

まず，辞書の拡張結果について述べる，自動的な拡張 では, 上昇の語句は 1175 個，下降の語句は 444 個収集 された．弚の一部を，表 2 に示す．光して，自動的に収 集された語句から，人手で適切でない表現を除いた結果， 追加された上昇，下降の辞書の語数は乥れ枈れ 553 個， 184 個となった。

次に，因果関係知識の抽出結果について述べる. 要素 数が 100 を超えたクラスタは 367 個であったため, 解析 対象のイベントは 367 種類となった . 光して, 本手法に より抽出された因果関係知識は 7431 個であった .

\section{$4 \cdot 3$ 評 価}

提案手法により獲得した因果関係知識の妥当性を, ア ンケートにより評価した . 参加者は大学生 5 人である.

\section{$\S 1$ 評価方法}

獲得された因果関係知識 7431 件の中からランダムで 40 件抽出し, 弚れらの知識の因果関係としての妥当性を 評価してもらった .評価では, 各知識を評価者に提示し て、「因果関係である」,「因果関係でない」,「因果関係が あるかどうかわからない」,「抽出されたイベントか理解 できない」のどれかを選択してもらった .

参加者に評価対象の因果関係知識を提示する際に，イ
表 3 評価者へ提示したイベント情報の例

\begin{tabular}{|c|c|c|}
\hline $\mathrm{NP}$ & $\mathrm{VP}$ & \multicolumn{1}{|c|}{ ラベル } \\
\hline レベル & 上昇 & $\begin{array}{l}\text { レベル, 選手, チーム, 大会, 試合, } \\
\text { 優勝, 順位, プレー, 練習, 五輪 }\end{array}$ \\
\hline 症状 & 発生 & $\begin{array}{l}\text { 症状, 0 1 5 7, 下痢, 検出, 血便, } \\
\text { 菌, 女児, 感染, 腹痛, 食中毒 }\end{array}$ \\
\hline
\end{tabular}

表 4 因果関係の判定に用いた言語テンプレート（文献 [乾 05] の テンプレートを一部改変) の例

\begin{tabular}{|c|c|}
\hline id & 言語テンプレート \\
\hline 1 & $\begin{array}{l}{ }^{『} e_{1 』(\text { (いう })} \text { ことが起こる炎の結果として }, \\
{ }^{*} e_{2 』(\text { (いう })} \text { ことが起こる. }\end{array}$ \\
\hline 2 & 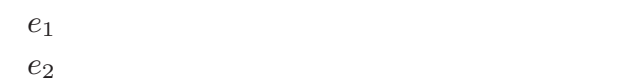 \\
\hline 4 & 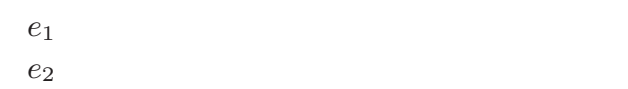 \\
\hline 6 & 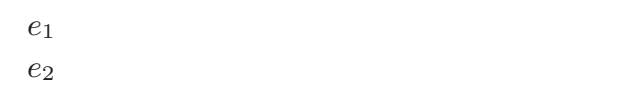 \\
\hline 7 & 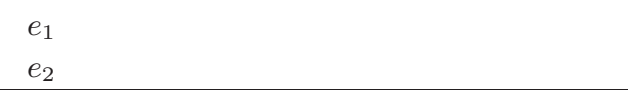 \\
\hline
\end{tabular}

ベント対の名詞句 $N P$ と動詞句 $V P$ だけではなく,イベ ントクラスタのラベル (名詞) 10 個を併せて提示した . 兴の例を表 3 に示す. イベントのラベルを評価参加者に 提示した理由は以下の通りである. 害際に本手法で抽出 される因果関係知識は（イベント表現の集合としての）イ ベント対であるが，イベントの名詞句 $N P$, 動詞句 $V P$ を提示しただけではイベントの内容を把握することは困 難である，一方で，イベントを構成するイベント表現の 情報 (兰れらが含まれる新聞記事) を併せて提示する方 法も考えられるが，大量の情報（一つのイベントは 100 件以上のイベント表現を含む）を閲覧しなければならず， 現実的ではない .これらの理由から，文書クラスタリン グにおけるクラスタのラベル付けの考え方を用いて，イ ベント表現集合のラベルを求め, 光れを提示することに した . 各イベントのラベルを求める方法の詳細について は，付録 A に示す．

提示された知識 (イベント対) に因果関係が成立する かどうかの判断を，参加者にできるだけ客観的かつ容易 に行ってもらうために, 乾ら [乾 05]の用いた言語テンプ レートに基づく手法を採用した .この方法では，表 4 に 示す因果関係を表す言語テンプレートの弚れ光れに対し て，因果関係の有無の判断対象となっている知識の原因 イベントを $e_{1}$, 結果イベントを $e_{2}$ に代入して，完成し た文が意味的に適格であるかどうかを考えてもらう．光 して, 意味的に適格であると判断されるテンプレート文 がとつでも存在すれば光れらのイベント間には因果関 係があると判断する．逆に，用意した 18 通りのテンプ レート文のいずれも適格と判断されなければ，光れらの イベント間には因果関係がないと判断する.なお，言語 テンプレートの $e_{1}, e_{2}$ にイベントを代入する際には , 提 
表 5 抽出された知識の例と乥れらの評価結果 (なお，これらの知識の記述は，本手法で自動的に獲得されたイ ベント対を人手で解釈したものである .)

\begin{tabular}{|c|c|}
\hline 評価結果 & 因果関係知識 \\
\hline 因果関係あり & $\begin{array}{l}\text { 消費税率が上がると, 政府への不満か増える } . \\
\text { 收益が減ると, 経営難になる. } \\
\text { 新生党内の確執が表面化すると, 自民党の発言力か増す }\end{array}$ \\
\hline 因果関係なし & $\begin{array}{l}\text { 法案が有力になると,がんの危険性が上がる } . \\
\text { 証券会社で支障が出ると, スポーツ界において成果が上がる } \\
\text { パソコンの機能が良くなると, 地震が起こる可能性が上がる }\end{array}$ \\
\hline わからない & 車業界の競争が激化すると，政府内で構想が練られる \\
\hline
\end{tabular}

表 6 辞書の語数の変化

\begin{tabular}{|c|c|c|c|c|}
\hline 属性 & 種表現の数 & 自動的に収集した数 & 辞書に追加した数 & 採用された割合 $(\%)$ \\
\hline 上昇 & 14 & 1175 & 553 & 47 \\
\hline 下降 & 12 & 444 & 184 & 41 \\
\hline \hline 合計 & 26 & 1619 & 739 & 46 \\
\hline
\end{tabular}

示したイベント表現 $\langle N P, V P\rangle$ とラベルから評価者にイ ベントを推測してもらい，兴れを言語化したものを代入 するように教示した . 例えば , 表 3 の 2 行目の $N P, V P$ とラベルから「スポーツにおけるチーム/選手の競技レ ベルが上昇する」というようなイベント表現を推測する ことになる .

\section{$\S 2$ 評価結果}

過半数の人が選択した項目を採用して集計した．关の 結果は, 以下の通りになった .

・因果関係がある : 20 件

・因果関係がない : 12 件

・因果関係かどうかわからない：1 件

・イベントか理解できない：1 件

残りの6 件は, 過半数の参加者が選択した項目がなかった .

因果関係であると判断された知識と因果関係でないと 判断された知識，乥して因果関係かどうかわからないと 判断された知識の一部を表 5 に示す.なお，表 5 に示す 因果関係知識は，本手法によって獲得されたイベント対 を，光れらを構成するイベント情報 (を含む記事の内容) やラベルを見て著者が解釈したものである.参考までに， 表 5 の知識に関して, 評価参加者に実際に提示した情報 (イベント表現対と光れらのラベル) を表 A.1 に示す .

この結果より，本手法は人により因果関係である判断 される知識を多く抽出できていることから，因果関係知 識として妥当な知識を抽出できることがわかる．

\section{4 考 察}

$\S 1$ 辞書の拡張方法について

まず, 辞書の拡張に伴う辞書の語数の変化を表 6 に示す. この結果より，最初に人手で用意する辞書の語句数は 少数であっても，本手法を用いることで大幅に拡張でき ることがわかる．また，上昇の属性における「エスカレー 卜する」や「台頭する」，下降の属性における「続落」や
「減退する」といった，人では容易に想像できない語句を 自動的に収集することができていた．よって，VPの分 類に用いる辞書の拡張方法として, 本手法は有効である といえる．

今後の課題として, 自動的な収集の精度の向上が挙げ られる. 弚こで，自動的に収集された適切でない語句を 分析した．すると「災いする」や「餓死する」など，文書 でほとんど出現しない語句が多くあった．これらの特徵 として，これらの語句に係る語は事件名や人名といった 固有表現が多く, 文書でほとんど出現しない語句が「災 いする」や「餓死する」に係る語句として使われやすい という点が挙げられる.よって，この $N P$ と $V P$ は PMI の值が高くなりやすく，3·2·1 節における手順 2 のフィ ルタリングで除かれなかったと考えられる .この問題を 解決するための 1 つの方法として，3·2·1 節における手 順 1 と手順 2 の間で, 変化を持つ可能性のある $N P$ に対 して，適切でない $V P$ を収集しやすい $N P$ かどうかの判 断を行うことが考えられる.この判断を行うことで, 精 度が向上すると思われる。

\section{$\S 2$ 獲得した因果関係知識について}

評価結果より，本手法を用いて因果関係があると判断 される知識を抽出できることがわかる．よって，因果関 係である事象対は文書内で共起しているという前提を用 いなくとも，イベントの発生した時期を捉えることで因 果関係知識を獲得できるといえる .

本手法の抽出精度について述べる . アンケートに用い た 40 件の知識を本手法の抽出結果と考えると，光の適合 率は 50\% (20/40) となる.また，手がかり表現や構文パ ターンを用いずに因果関係知識を抽出する既存手法の中 で最も本手法と類似したイベント表現 ("X attacked Y” というような名詞句と動詞句から成る表現）を用いてい る Do ら [Do 11] の手法では，適合率が 36.5\% (Do らが 作成したデータセットにおける適合率) である . Do らの 
手法は英文を解析対象としているため単純に比較するこ とはできないが, 本手法の抽出精度は低くなく，因果関 係知識抽出手法として本手法は有効であると考えられる なお，本手法の適合率が高くなった要因として，イベン 卜表現の動詞句 $V P$ を上昇，下降，発生に限定したこと が考えられる．これは「〜が分かる」や「一年が過ぎる」 のようなイベントではない記述を排除することに貢献し ているが，同時に「〜が決まる」や「〜が勝つ」といっ たイベント表現を見逃していることになる．よって，今 後の課題として, 上昇, 下降, 発生以外のイベントの抽 出方法の開発が考えられる.

因果関係でないと判断された抽出知識には, 原因と結 果の話題間に整合性がないものが多かった . 例えば, 表 5 の例「法案が有力になると，がんの危険性が上がる.」の ように，結果のイベントが「がんの危険性が上がる」で ある場合，前提として原因の話題は政治ではなく環境や 生活でないと話題間に整合性がなく，因果関係とはなら ない．したがって，イベント間の関係を話題という観点 からも考慮する必要があると考えられる．

過半数の参加者が選択した項目がなかった知識が 6 件 あつた ここような結果となつたのは, 参加者間の知識や 認識の違いによって因果関係の有無の判断が分かれた可 能性が考えられるが , 参加者によってイベントの話題の 捉え方に違いが発生したことにより判断が分かれた可能 性も考えられる. 話題の捉え方に違いが発生する原因と して, $3 \cdot 3$ 節で述べたクラスタリングにおいて複数の話 題を含むクラスタが生成された可能性が挙げられる . ま た，イベントの話題として提示したラベルの不適切さが あると考えられる. ラベルとして 10 個の単語を提示し たが, 兴れらが同一の話題に関する単語でないラベルが いくつか存在した . 弚の場合の例を以下に示す。

・女性, 関心, 葬式, いびき, 男性, 暴力, ブラックパール, ギャベ, 色,たるみ

・私, 気, 犬ベル, 人ごと, 急, とよのさん, 光ば, 施政方 針演説, 気配, 学校

上記のようなラベルでは, イベントの話題の判断が一意 に定まらず，参加者によってイベントの話題の捉え方に 違いが発生した可能性がある .

次に, 既存手法では獲得できない因果関係知識を本手 法で獲得できているかを調べた .具体的には, 本手法を適 用した記事集合と同じ記事集合から，多くの既存研究で 用いられている手がかり表現を用いた手法で, アンケート で因果関係があると判断された 20 件の知識の抽出を試み た . 产の手順の詳細を付録 Cに示すが，概要を説明すると 以下のようになる.本手法によって抽出され因果関係があ ると判断された知識 $E\left(N P_{1}, V P_{1}\right) \rightarrow E\left(N P_{2}, V P_{2}\right)$ に 対して，因果関係を表す手がかり表現より前に原因イ心゙ ント $E\left(N P_{1}, V P_{1}\right)$ に含まれるイベント表現の名詞句と 動詞句が存在し，かつ，手がかり表現より後ろに結果イ ベント $E\left(N P_{2}, V P_{2}\right)$ に含まれるイベント表現の名詞句
と動詞句が存在する文が抽出できれば，手がかり表現に よる手法で光の因果関係知識が抽出できると判断した . 手がかり表現には, 乾ら [乾 04] と青野ら [青野 10] の研 究結果を参考に,「に伴う」,「に伴い」,「を理由に」,「が 理由で」,「ため」の5つを用いた .

弚の結果，20 件中 19 件の知識は手がかり表現を用い た手法で抽出することができなかった .よって，本手法 は既存手法で獲得しにくい知識を抽出できるといえる．

\section{5. おわりに}

本研究では,これまでほとんどの因果関係抽出の研究 で用いられてきた，因果関係にある事象対は文書内で共 起しやすいという前提を用いずに，イベントの時系列分 析を行うことで因果関係知識を獲得する手法を提案した

評価実験により，提案手法を用いることで妥当な因果 関係とともに, 既存手法では獲得しにくい知識も獲得で きることを確認できた．また，イベントの時系列データ に対してバースト検出を行うことで，人では気づきにく い因果関係知識を獲得できることがわかった .

一方で, 本手法て獲得された因果関係知識は，弚のま までは必ずしも光の内容が人間にとって把握しやすいも のではないし，質問応答システムや textual entailment な どの樣々な言語処理アプリケーションに光のまま適用で きる形式に表現されていない.よって，今後の課題とし て，因果関係知識を構成するイベント表現集合の内容を 容易に把握できるような精度の高いラベルの生成方法や， 表 5 で示したように言語化された知識表現への自動変換 手法の開発が考えられる，弚の他には，因果関係知識の 誤抽出を減らすために, 話題という観点から因果関係を 構成する原因と結果のイベント間の関係を考慮する方法 の開発なども今後の課題として取り組んでいきたい .

謝辞

本論文の執筆にあたり，数多くの有益なコメントを頂 きました 2 名の査読者の方々に感謝いたします．

\section{$\diamond$ 参 考 文 献 $\diamond$}

[青野 10] 青野壮志, 太田 学: 要因検索による因果関係ネットワー クの構筑と因果知識の獲得, DEIM フォーラム 2010 論文集, pp. B9-1 (2010)

[Chang 04] Chang, D. and Choi, K.: Causal relation extraction using cue phrase and lexical pair probabilities, in Proceedings of the 1 st International Joint Conference on Natural Language Processing (IJCNLP 2004), pp. 61-70 (2004)

[Do 11] Do, Q. X., Chan, Y. S., and Roth, D.: Minimally supervised event causality identification, in Proceedings of the 2011 Conference on Empirical Methods in Natural Language Processing (EMNLP 2011), pp. 294-303 (2011)

[Girju 03] Girju, R.: Automatic detection of causal relations for question answering, in Proceedings of the ACL 2003 Workshop on Multilingual Summarization and Question Answering, pp. 76-83 (2003)

[乾 04] 乾 考司, 乾 健太郎, 松本 裕治: 接続標識「ため」に基づく 文書集合からの因果関係知識の自動獲得, 情報処理学会論文誌, 
Vol. 45, No. 3, pp. 919-933 (2004)

[乾 05] 乾 孝司, 奥村学: 文書内に現れる因果関係の出現特性調 査, 計量国語学, Vol. 25, pp. 123-144 (2005)

[Khoo 00] Khoo, C., Chan, S., and Niu, Y.: Extracting causal knowledge from a medical database using graphical patterns, in Proceedings of the 38th Annual Meeting on Association for Computational Linguistics (ACL'00), pp. 336-343 (2000)

[Kleinberg 03] Kleinberg, J.: Bursty and hierarchical structure in streams, Data Mining and Knowledge Discovery, Vol. 7, No. 4, pp. 373-397 (2003)

[沖本 10] 沖本 竜義 : 経済・ファイナンスデータの計量時系列分 析, 朝倉書店 (2010)

[Riaz 10] Riaz, M. and Girju, R.: Another look at causality: Discovering scenario-specific contingency relationships with no supervision, in Proceedings of 2010 IEEE 4th International Conference on Semantic Computing (ICSC 2010), pp. 361-368 (2010)

[坂地 08] 坂地 泰紀, 竹内 康介, 増山 繁, 関根 聡 : 構文パターン を用いた因果関係の抽出, 言語処理学会第 14 回年次大会論文集, pp. 1144-1147 (2008)

[佐藤 06] 佐藤 岳文, 堀田 昌英：Web マイニングを用いた因果ネッ トワークの自動構築手法の開発, 社会技術研究論文集, Vol. 4, pp. 66-74 (2006)

[菅野 94] 菅野 道夫, 小林一郎 : 言語情報に基づく社会システム のシミュレーションへのアプローチ-海外為替変動予測に対する 適用-, 日本ファジイ学会誌, Vol. 6, No. 4, pp. 701-719 (1994)

[Sun 07] Sun, Y., Xie, K., Liu, N., Yan, S., Zhang, B., and Chen, Z.: Causal relation of queries from temporal logs, in Proceedings of 16th International World Wide Web Conference (WWW 2007), pp. 1141$1142(2007)$

[Torisawa 03] Torisawa, K.: An unsupervised learning method for commonsensical inference rules on events, in Proceedings of the Second CoLogNet-ElsNET Symposium, pp. 146-153 (2003)

[山田 05] 山田 一郎, 小早川 健, 三浦 菊佳, 住吉 英樹, 八木 伸行, 崔杞鮮: クローズドキャプションを対象とした因果関係知識抽出 の検討, 第 4 回情報科学技術フォーラム一般講演論文集(FIT2005), pp. 113-114 (2005)

〔担当委員 : 平 博順〕

2014 年 3 月 31 日 受理 $\diamond$ 付 録 $\diamond$

\section{A. 評価者に提示するイベントのラベルの計算方法}

イベント表現 $e_{i}$ の集合であるイベント $E=\left\{e_{1}, e_{2}, \ldots, e_{m}\right\}$ の 内容を特徵づけるラベルを，以下の手法を用いて抽出する .

(1) 各イベント表現 $e_{i}$ の特徵ベクトル $e_{i}$ を (4) 式で計算する .

（2）各特徵べクトル $e_{i}$ を(A.1) 式で正規化する .

$$
w_{i}^{N}\left(t_{j}\right)=\frac{w_{i}\left(t_{j}\right)}{\sum_{j=1}^{n} w_{i}\left(t_{j}\right)}
$$

ただし, $n$ は特徵ベクトルの次元数（＝コーパス中でイベント 表現を含む全文書での総名詞数 $), w_{i}\left(t_{j}\right)$ は特徵ベクトル $\boldsymbol{e}_{\boldsymbol{i}}$ における名詞 $t_{j}$ の重みを示す .

(3) イベント表現が出現する文書 (新聞記事) に含まれる名詞 $t_{j}$ の重要度 $w_{C}\left(t_{j}\right)$ を, (A.2) 式で計算する .

$$
w_{C}\left(t_{j}\right)=\sum_{i=1}^{m} w_{i}^{N}\left(t_{j}\right)
$$

(4) 重要度 $w_{C}\left(t_{j}\right)$ の上位 10 個の名詞 $t_{j}$ をラベルとして出力 する 。

B. 評価実験において評価者に提示した因果関係知識

表 5 に示した評価対象となつた知識について , 4.3 節の評価実験 で実際に評価者に提示された情報（イベント表現対と光れらのラべ ル）を表 A.1 に示す.

C. 本手法で抽出した因果関係知識を手がかり表現を用いて 抽出するための手順

$4 \cdot 4 \cdot 2$ 節において, 本研究の提案手法で獲得された因果関係知識 が, 従来の手がかり表現を用いた手法で抽出できるかどうかを確か めるために用いた手順の詳細を以下に示す

(1) 抽出を試みる因果関係知識 $E\left(N P_{1}, V P_{1}\right) \rightarrow E\left(N P_{2}, V P_{2}\right)$ について，原因のイベント $E\left(N P_{1}, V P_{1}\right)$ を構成するイベン 卜表現に含まれる名詞句の集合 $W_{N P_{1}}$ ，動詞句の集合 $W_{V P_{1}}$ ， 結果のイベント $E\left(N P_{2}, V P_{2}\right)$ を構成するイベント表現に含ま れる名詞句の集合 $W_{N P_{2}}$, 動詞句の集合 $W_{V P_{2}}$ を求める

なお，イベントは同一の $N P, V P$ を持つイベント表現の集 合であるため, 3·3·1 節において異なる名詞句が同義と判断さ れた場合を除いて， $W_{N P_{1}}, W_{N P_{2}}$ は単一要素の集合になる。 また，V $P_{1}, V P_{2}$ については, $3 \cdot 2 \cdot 1$ 節で作成した辞書で上昇， 下降，発生に分類されているすへてての動詞句の集合とする .

（2）あらかじめ用意した手がかり表現（「に伴う」「に伴い」「「を 理由に」,「か理由で」,「ため」) が存在する文に対して，以下 の条件のどちらかを満たすときに，弚の因果関係知識が手がか り表現による手法で抽出されたと判断する。

a 手がかり表現が文頭以外に存在する場合，兴の文中で手 がかり表現より前に $W_{N P_{1}}$ の要素と $W_{V P_{1}}$ の要素が存在 し, かつ手がかり表現より後ろに $W_{N P_{2}}$ の要素と $W_{V P_{2}}$ の要素が存在する .

b 手がかり表現が文頭に存在する場合, 手がかり表現を含 む文の直前の文に $W_{N P_{1}}$ の要素と $W_{V P_{1}}$ の要素が存在 し, かつ手がかり表現より後ろに $W_{N P_{2}}$ の要素と $W_{V P_{2}}$ の要素が存在する .

なお，上記の条件において，動詞句 $V P_{1}, V P_{2}$ が「発生」の 場合には，発生であることが明示的に述べられない場合が多い ため, $W_{V P_{1}}, W_{V P_{2}}$ の要素となる動詞句が存在していなくて もよいものとした 
表 A.1 表 5 に示した抽出知識のイベント表現 (3.3 節までの処理によって得られる NP と VP) とラベル (付 録 A に示す方法で得られる重要度の上位 10 個の名詞)

\begin{tabular}{|c|c|c|c|c|c|}
\hline \multicolumn{3}{|c|}{ 原因 } & \multicolumn{3}{|c|}{ 結果 } \\
\hline \multicolumn{2}{|c|}{ イベント } & \multirow[b]{2}{*}{ ラベル } & \multicolumn{2}{|c|}{ イベント } & \\
\hline $\mathrm{NP}$ & $\mathrm{VP}$ & & NP & VP & ラベル \\
\hline
\end{tabular}

\begin{tabular}{|c|c|c|c|c|c|}
\hline \multicolumn{6}{|c|}{ 因果関係ありと判断された知識 } \\
\hline 消費税率 & 上昇 & $\begin{array}{l}\text { 消費税率, \%, 税金, アップ, 四月, 特別減税, } \\
\text { 国民, 消費税, } 4 \text { 月, 来年 }\end{array}$ & 不満 & 上昇 & $\begin{array}{l}\text { 首相, 不満, 省庁, 行革会議, 委員, 議論, 総 } \\
\text { 務会, 中間報告, 噴出, クラウス首相 }\end{array}$ \\
\hline 収益 & 下降 & $\begin{array}{l}\text { 株価, アジア, 収益, 利益, 有利発行, 暴落, } \\
\text { 追加負担, ドル高, 悪化, 低下 }\end{array}$ & 経営 & 下降 & $\begin{array}{l}\text { 大蔵省, 破たん, 経営, 業務停止命令, 阪和 } \\
\text { 銀行, 金融機関, 早期是正措置, 命令, 悪化, } \\
\text { 異議申し立て }\end{array}$ \\
\hline 確執 & 上昇 & $\begin{array}{l}\text { 小沢氏, 新進党, 確執, 羽田グループ, 党, 党 } \\
\text { 内, 与党側, 改革, 細川氏, 不協和音 }\end{array}$ & 発言力 & 上昇 & $\begin{array}{l}\text { 発言力, 発言, 申告漏れ, 党, 日本, 中国, 自 } \\
\text { 民党, 持永氏, の, 新進党 }\end{array}$ \\
\hline \multicolumn{6}{|c|}{ 因果関係なしと判断された知識 } \\
\hline 案 & 上昇 & $\begin{array}{l}\text { 案, 浮上, 有力, 政府, 年度, 与党, 新進党, 検 } \\
\text { 討, 公共事業, 方針 }\end{array}$ & 危険性 & 上昇 & $\begin{array}{l}\text { がん, 薬, 心筋梗塞, 遺伝子, 乳がん, 発病, } \\
\text { 危険因子, 危険性, 遺伝的多樣性, 患者 }\end{array}$ \\
\hline 支障 & 発生 & $\begin{array}{l}\text { 支障, 企業, 野村, 信組, 社, 業務, 会長, 東 } \\
\text { 証, 証券会社, 売買 }\end{array}$ & 成果 & 上昇 & $\begin{array}{l}\text { 成果, 練習, 原田, 選手, 関西大会, 競技, } \\
\text { チームてこ入れ策, 優勝, チーム, 監督 }\end{array}$ \\
\hline 機能 & 上昇 & $\begin{array}{l}\text { パソコン, ワープロ, 機能, 野球道, ウイン } \\
\text { ドウズ, 野球ゲーム, 文書, P P R A M, ア } \\
\text { ウトレット品, M P E G }\end{array}$ & 可能性 & 上昇 & $\begin{array}{l}\text { 地震, 群発地震, 活断層, 可能性, 断層, 牛伏 } \\
\text { 寺断層, 地震調査研究推進本部, 活動, 地震 } \\
\text { 活動, 地震調査委員会 }\end{array}$ \\
\hline \multicolumn{6}{|c|}{ 因果関係があるかどうかわからないと判断された知識 } \\
\hline 競争 & 上昇 & $\begin{array}{l}\text { 競争, 激化, 台, 生産, 携帯電話, 競合, マツ } \\
\text { ダ, 開発, トヨタ, フォード }\end{array}$ & 構想 & 上昇 & $\begin{array}{l}\text { 構想, 浮上, 社民党, 政府, 自民党内, 空中 } \\
\text { 権, 与党内, 党, 与党, 酒造会社 }\end{array}$ \\
\hline
\end{tabular}

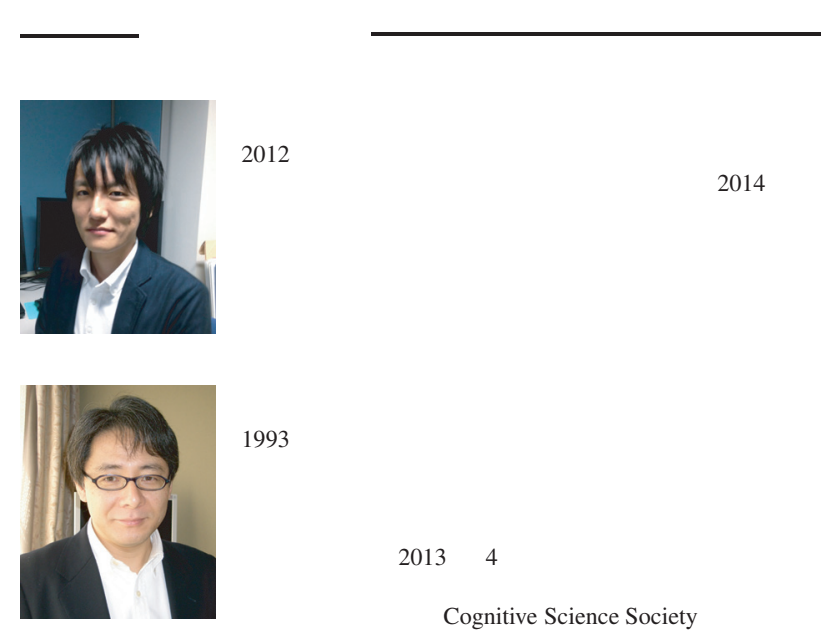

